\title{
Interactions between $M$ protein and other structural proteins of severe, acute respiratory syndrome-associated coronavirus
}

\author{
Yi-Ching Hsieh $\cdot$ Hui-Chun Li $\cdot$ Shih-Chi Chen • \\ Shih-Yen Lo
}

Received: 2 May 2008/Accepted: 21 August 2008/Published online: 16 September 2008

(C) National Science Council Taipei 2008

\begin{abstract}
Severe acute respiratory syndrome-associated coronavirus (SARS-CoV) structural proteins (S, E, M, and NC) localize in different subcellular positions when expressed individually. However, SARS-CoV M protein is co-localized almost entirely with $\mathrm{S}, \mathrm{E}$, or NC protein when co-expressed in the cells. On the other hand, only partial co-localization was observed when S and E, S and NC, or E and $\mathrm{NC}$ were co-expressed in the cells. Interactions between SARS-CoV $\mathrm{M}$ and other structural proteins but not interactions between $\mathrm{S}$ and $\mathrm{E}, \mathrm{S}$ and $\mathrm{NC}$, or $\mathrm{E}$ and $\mathrm{NC}$ were further demonstrated by co-immunoprecipitation assay. These results indicate that SARS-CoV M protein, similar to the $\mathrm{M}$ proteins of other coronaviruses, plays a pivotal role in virus assembly. The cytoplasmic C-terminus domain of SARS-CoV $\mathrm{M}$ protein was responsible for binding to NC protein. Multiple regions of $\mathrm{M}$ protein interacted with $\mathrm{E}$ and $\mathrm{S}$ proteins. A model for the interactions between SARS-CoV M protein and other structural proteins is proposed. This study helps us better understand
\end{abstract}

Electronic supplementary material The online version of this article (doi:10.1007/s11373-008-9278-3) contains supplementary material, which is available to authorized users.

Y.-C. Hsieh · H.-C. Li · S.-C. Chen · S.-Y. Lo ( ()

Graduate Institute of Molecular and Cellular Biology, Tzu Chi University, 701, Section 3, Chung Yang Road, Hualien, Taiwan e-mail: losylo@mail.tcu.edu.tw

H.-C. Li · S.-Y. Lo

Graduate Institute of Medical Sciences, Tzu Chi University, Hualien, Taiwan

S.-Y. Lo

Department of Laboratory Medicine and Biotechnology, Tzu Chi University, Hualien, Taiwan protein-protein interactions during viral assembly of SARS-CoV.

Keywords SARS-CoV $\cdot$ Membrane protein .

Structural proteins · Co-localization .

Co-immunoprecipitation

\section{Introduction}

Severe acute respiratory syndrome (SARS), a new infectious disease typically associated with fever, shortness of breath, cough, and pneumonia, first emerged in southern China in November 2002. Within months of the outbreak, SARS had spread globally, affecting over 8,000 patients in 29 countries with 774 fatalities [1]. The etiology of SARS is associated with a newly discovered coronavirus, SARSassociated coronavirus (SARS-CoV) [2-4]. SARS-CoV infects many organs, including lungs, liver, and immune cells $[5,6]$. Subsequent studies have indicated that the SARS-CoV is of animal origin [7], and its precursor is still present in animal populations within the region. Although the global outbreak of SARS has been contained, there are serious concerns over its re-emergence. To date, no specific treatment exists for this disease. Thus, further basic and clinical research is required to control the disease.

SARS-CoV is phylogenetically distinct, and only distantly related to the other coronavirus clades [8, 9]. Coronaviruses are exceptionally large RNA viruses and employ complex regulatory mechanisms to express their genomes [10]. The genome structure, gene expression pattern and protein profiles of SARS-CoV are similar to those of other coronaviruses. Nine SARS-CoV specific mRNAs were synthesized in virus-infected cells [11]. These RNA were predicted to encode 4 structural proteins 

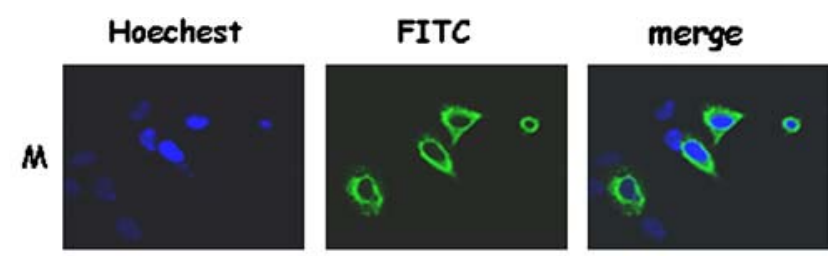

E
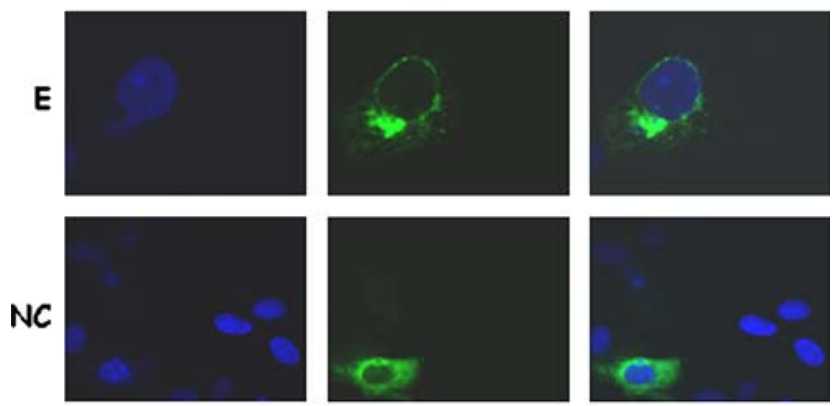

$S$
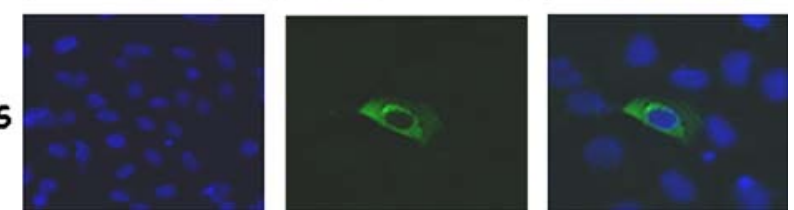

Fig. 1 Differential subcellular localizations of SARS-CoV structural proteins S, E, M and $\mathrm{NC}$ ) when they were expressed individually. Cells were transfected with the plasmid expressing M-V5, the plasmid expressing myc-E protein, the plasmid expressing $\mathrm{NC}$ protein, or the plasmid expressing $\mathrm{S}$ protein. After transfection, cells were fixed and stained with mouse anti-V5, mouse anti-myc, rabbit anti-NC, rabbit anti-S antibodies. Green color, M, NC, S, or E protein staining; blue color, DAPI staining

(spike, envelope, membrane, and nucleocapsid proteins), 16 non-structural proteins, and 8 accessory proteins. Previous studies on various coronaviruses indicated that the four structural proteins (S, E, M, and NC) play roles in virion morphogenesis $[12,13]$. NC binds to viral RNA to form the nucleocapsid. Co-expression of $\mathrm{M}$ and $\mathrm{E}$ proteins together can form virus-like particles [14, 15]. Interactions between the $\mathrm{M}$ and $\mathrm{E}$ proteins and nucleocapsids result in virus budding through the cellular membrane [16]. Through the interaction with $\mathrm{M}$ protein, $\mathrm{S}$ protein is

Fig. 2 (a) Co-localization of SARS-CoV M protein with S, E, or NC protein when co-expressed in Vero E6 cells. Cells were co-transfected with plasmids expressing the M-V5 and NC (upper), S (middle), or myc-E (lower) proteins. After transfection, cells were fixed and stained with rabbit anti-NC and mouse anti-V5 antibodies (upper), or rabbit anti-S and mouse anti-V5 antibodies (middle), or mouse antimyc and goat anti-mouse conjugated with $\mathrm{Cy} 3$ followed by anti-V5FITC antibody (lower). Green color, M protein staining; red color, $\mathrm{NC}$ (or S, or E) protein staining; blue color, DAPI staining; yellow color, co-localization of $\mathrm{M}$ and other structural proteins. (b) Partial co-localization of $\mathrm{E}$ and $\mathrm{NC}, \mathrm{S}$ and $\mathrm{NC}$, or $\mathrm{E}$ and $\mathrm{S}$ proteins when they were co-expressed in Vero E6 cells. Cells were co-transfected with plasmids expressing myc-E and NC proteins (upper); $\mathrm{S}$ and myc-NC proteins (middle), and myc-E and $\mathrm{S}$ proteins (lower). After transfection, cells were fixed and stained with rabbit anti-NC (or anti-S) and mouse anti-myc antibodies incorporated into the viral envelope $[17,18]$ and the mature virions are released from the cells. These studies suggest that coronavirus $M$ protein $[19,20]$ plays a crucial role in the assembly of virus particles. Like other coronaviruses, SARS-CoV assembles at and buds into the lumen of the endoplasmic reticulum-Golgi intermediate compartment [21]. Accumulation of the viral envelope proteins at this compartment is a prerequisite for virus assembly [22]. Immuno-EM (electron microscopy) revealed that budding occurred at membranes of the ERGIC and the Golgi region

\section{A}
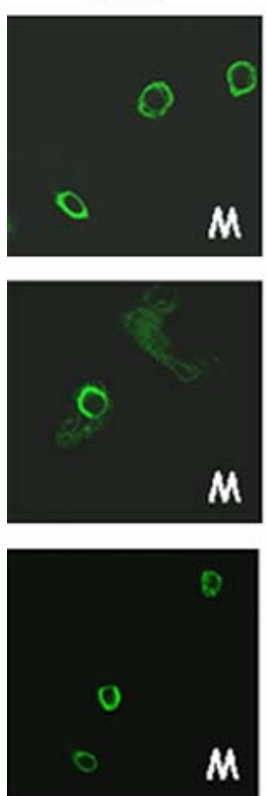

B
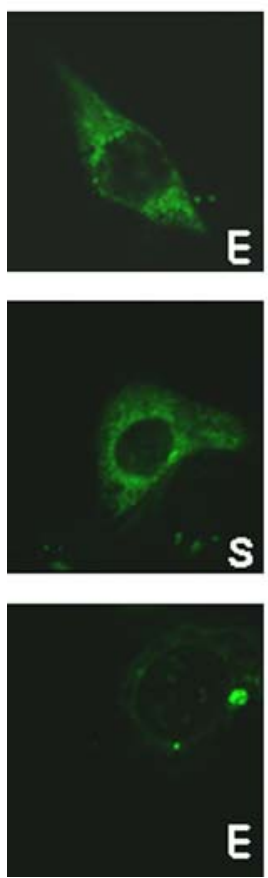

Cy3
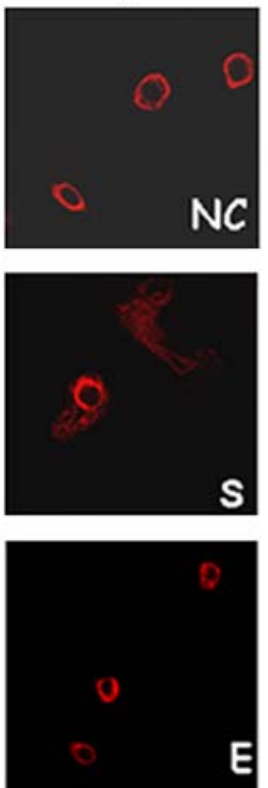

Cy3
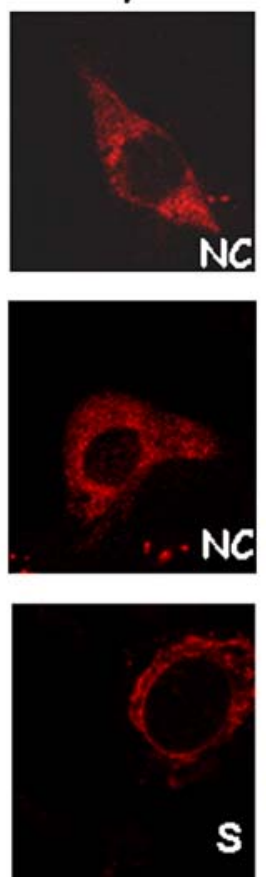
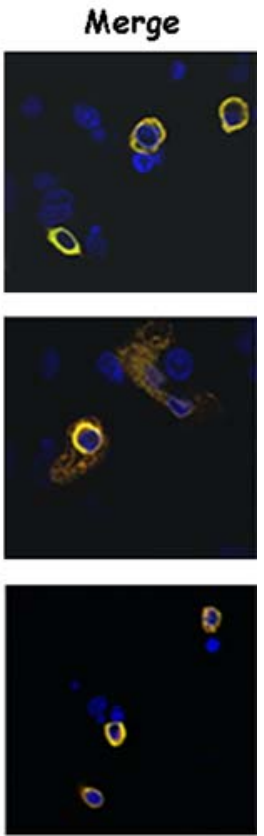

Merge
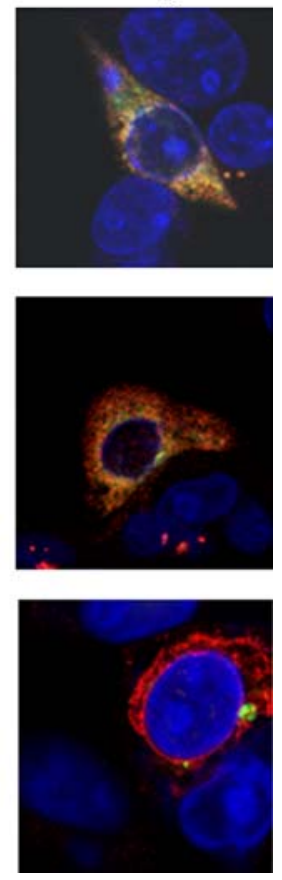


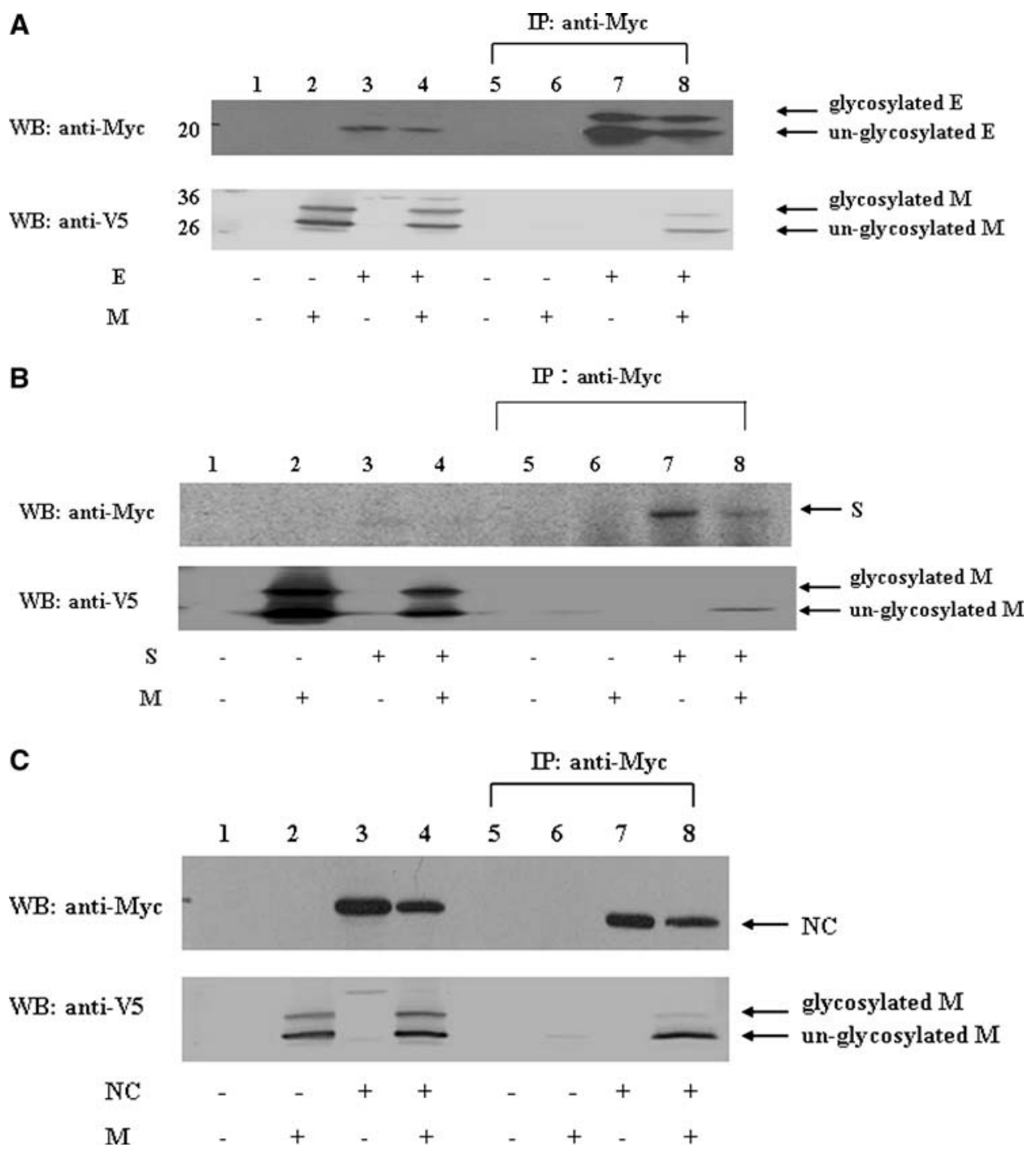

Fig. 3 (a) SARS-CoV M interaction with E protein. Vero E6 cells were transfected with vector alone (lanes 1 and 5), plasmid encoding M-V5 (lanes 2 and 6), plasmid encoding myc-E (lanes 3 and 7), or cotransfected with both plasmids (lanes 4 and 8). Cell lysates were directly analyzed by Western blotting (lanes 1-4) or immunoprecipitated with the anti-myc antibody prior to Western blotting (lanes 58). (b) SARS-CoV M interaction with S proteins. Vero E6 cells were transfected with vector alone (lanes 1 and 5), plasmid encoding M-V5 (lanes 2 and 6), plasmid encoding myc-S (lanes 3 and 7), or co-

as early as $3 \mathrm{~h}$ post infection, demonstrating that SARS$\mathrm{CoV}$ replicated surprisingly fast. Previous data also suggests that SARS-CoV established replication complexes at ER-derived membranes [21]. Later on, viral nucleocapsids were transported to the budding sites in the Golgi region where the viral glycoproteins accumulate and particle formation occurs. Assembly of SARS-CoV RNA packaging signal into virus-like particles is nucleocapsid dependent [23]. In this report, the protein-protein interactions among SARS-CoV structural proteins were studied using confocal microscopy and immunoprecipitation followed by Western blotting analysis. Results from this study transfected with both plasmids (lanes 4 and 8). Cell lysates were directly analyzed by Western blotting (lanes 1-4) or immunoprecipitated with the anti-myc antibody prior to Western blotting (lanes 58). (c) SARS-CoV M interaction with NC proteins. Vero E6 cells were transfected with vector alone (lanes 1 and 5), plasmid encoding M-V5 (lanes 2 and 6), plasmid encoding myc-NC (lanes 3 and 7), or co-transfected with both plasmids (lanes 4 and 8). Cell lysates were directly analyzed by Western blotting (lanes 1-4) or immunoprecipitated with the anti-myc antibody prior to Western blotting (lanes 5-8)

indicate that, similar to the $\mathrm{M}$ protein of other coronaviruses, SARS-CoV $M$ protein plays a crucial role in the interactions between SARS-CoV structural proteins.

\section{Materials and methods}

Plasmid construction

The construction of plasmids expressing full-length spike and nucleocapsid proteins or encoding full-length and deletion mutants of membrane protein plus a V5 tag was 


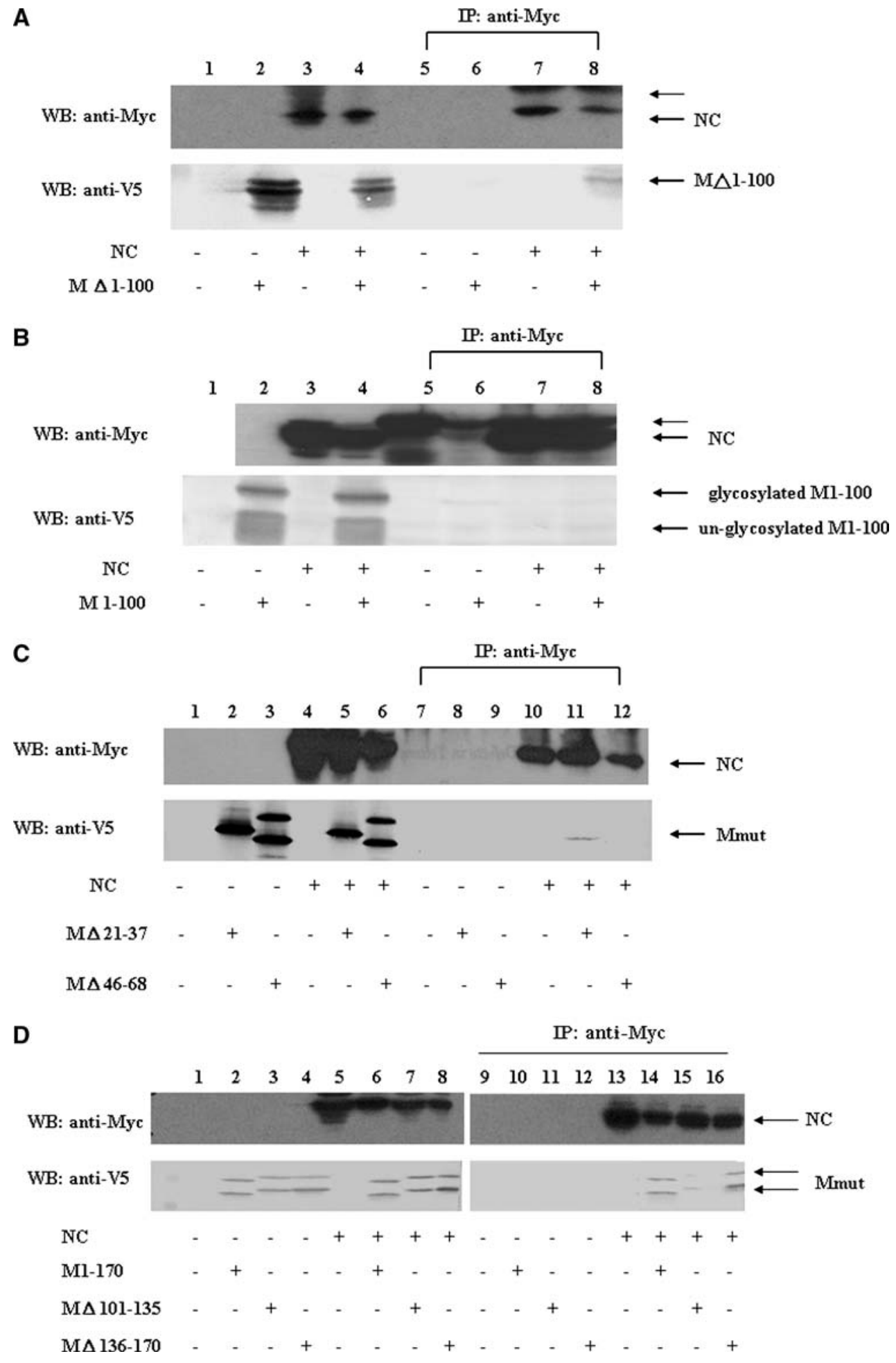

described previously [24, 25]. Similar strategies were performed to prepare the plasmids expressing full-length spike, envelope, and nucleocapsid proteins with different tags using primers listed in Supplementary Table I. Vector pcDNA3.1/V5-His A (Invitrogen, CA, USA) was used to add a V5-His tag at the C-terminus of the expressed protein while vector pcDNA3-cMyc tag [26] was used to add a myc tag at the N-terminus of the expressed protein.

All the expression plasmids were verified by sequencing. 
4 Fig. 4 Immunoprecipitation and Western blotting analyses of SARS$\mathrm{CoV} \mathrm{M}$ protein cytoplasmic C-terminus domain interaction with $\mathrm{NC}$ protein. (a) Vero E6 cells were transfected with vector alone (lanes 1 and 5), plasmid encoding cytoplasmic C-terminus domain of $\mathrm{M}$ protein (i.e. M protein without its first 100 amino acids) with a V5 tag (lanes 2 and 6), plasmid encoding myc-NC (lanes 3 and 7), or cotransfected with both plasmids (lanes 4 and 8). Cell lysates were directly analyzed by Western blotting (lanes 1-4) or immunoprecipitated with the anti-myc antibody prior to Western blotting (lanes 58). The cytoplasmic C-terminus domain of $\mathrm{M}$ protein interacted with $\mathrm{NC}$ protein. The protein larger than NC protein marked by the thin arrow is the immunoglobulin heavy chain (lower panel). More than one band was detected when the plasmid encoding the cytoplasmic Cterminus domain of $\mathrm{M}$ protein was expressed, possibly due to sample preparation without boiling treatment. (b) Vero E6 cells were transfected with vector alone (lanes 1 and 5), plasmid encoding the first 100 amino acids of M protein with a V5 tag (lanes 2 and 6), plasmid encoding myc-NC (lanes 3 and 7), or co-transfected with both plasmids (lanes 4 and 8). Cell lysates were directly analyzed by Western blotting (lanes 1-4) or immunoprecipitated with the anti-myc antibody prior to Western blotting (lanes 5-8). M protein without its cytoplasmic domain did not interact with $\mathrm{NC}$ protein. The protein larger than NC protein marked by the thin arrow is the immunoglobulin heavy chain. (c) Vero E6 cells were transfected with vector alone, plasmid encoding M $\triangle 21-37$ plus a V5 tag (or the plasmid encoding $\mathrm{M} \triangle 46-68$ plus a V5 tag), plasmid encoding myc-NC, or cotransfected with two plasmids (M $\triangle 21-37$ and myc-NC, M $\triangle 46-68$ and myc-NC). Cell lysates were directly analyzed by Western blotting (lanes 1-6) or immunoprecipitated with the anti-myc antibody prior to Western blotting (lanes 7-12). M protein without its first hydrophobic domain, but not $\mathrm{M}$ protein without its second hydrophobic domain interacted with $\mathrm{NC}$ protein. (d) Vero E6 cells were transfected with vector alone, plasmid encoding M1-170 with a V5 tag (or the plasmid encoding $\mathrm{M} \triangle 101-135$ plus a V5 tag, or the plasmid encoding $\mathrm{M} \triangle 136-170$ plus a V5 tag), plasmid encoding myc-NC, or cotransfected with two plasmids (M1-170 and myc-NC, M $\triangle 101-135$ and myc-NC, M $\triangle 136-170$ and myc-NC). Cell lysates were directly analyzed by Western blotting (lanes 1-8) or immunoprecipitated with the anti-myc antibody prior to Western blotting (lanes 9-18). All of the $\mathrm{M}$ cytoplasmic domain-deleted mutants interacted with $\mathrm{NC}$ protein

Protein expression in Vero E6 cells

Vero E6 cells were maintained in RPMI 1640 medium containing $10 \%$ fetal calf serum, $1 \%$ glutamine $(200 \mathrm{mM}$, Biological Industries, Israel), and $100 \mu \mathrm{g} / \mathrm{ml}$ of penicillin/ streptomycin (Gibco BRL, USA). The cells (2.5$2.7 \times 10^{5}$ ) were plated in the $35-\mathrm{mm}$ dish. After an overnight incubation, cells were infected with a recombinant vaccinia virus carrying the T7 phage RNA polymerase gene [27]. Two hours after infection, the cells were transfected with $0.4 \mu \mathrm{g}$ of plasmid DNA using Effectene transfection reagent (Qiagen, Germany). After $21 \mathrm{~h}$ of transfection, the recombinant proteins in the cells were analyzed.

\section{Immunoprecipitation assay}

The Vero E6 cells $\left(1 \times 10^{6}\right)$ were harvested $21 \mathrm{~h}$ after transfection and lysed in RIPA buffer $(150 \mathrm{mM} \mathrm{NaCl}, 1 \%$
NP40, 0.5\% deoxychloic acid, $0.1 \%$ SDS, $50 \mathrm{mM}$ Tris, $\mathrm{pH}$ 7.5). After full-speed centrifugation for $5 \mathrm{~min}$ in a microcentrifuge, the supernatant was incubated with mouse antiV5 monoclonal antibody (Invitrogen) or mouse anti-His monoclonal antibody (Santa Cruz Biotechnology, CA, USA) or mouse anti-myc monoclonal antibody (Oncogene, MA, USA) at $4^{\circ} \mathrm{C}$ overnight with shaking. The antigenantibody complex was separated with pansorbin (Merck, Germany). The immunoprecipitated pellet was boiled for $10 \mathrm{~min}$ in sampling buffer and then analyzed by SDSpolyacrylamide gel electrophoresis (PAGE) and Western blotting. In each experiment, $10 \%$ of cell lysates were used for expression analysis (by Western blotting assay directly) while $90 \%$ of cell lysates were used for the co-immunoprecipitation assay [25].

\section{Western blotting analysis}

For Western blotting analysis, cells were dissolved in sample preparation buffer after washing with PBS twice. SARS-CoV M protein is not detected in SDS-PAGE after regular boiling treatment [24]. Therefore, treatments at room temperature were used for antigen preparation (sample buffer containing $50 \mathrm{mM}$ of Tris- $\mathrm{HCl}$ (pH 6.8), $100 \mathrm{mM}$ dithiothreitol, $2 \%$ SDS, $0.1 \%$ bromophenol blue, and $10 \%$ glycerol, without boiling) to detect the expression of SARS-CoV M protein. A $4.5 \%$ acrylamide stacking gel and $12 \%$ separating gel were used in this study. When proteins with smaller size were analyzed (e.g., membrane protein deletion mutants), a $15 \%$ separating gel was used. After SDS-PAGE, the gel was transferred to PVDF paper (Pall Corporation, NY, USA). All procedures were carried out at room temperature, according to previously published procedures [26, 28, 29], except that the first antibody used in this assay was mouse anti-V5 monoclonal antibody (Invitrogen) or mouse anti-His monoclonal antibody (Santa Cruz Biotechnology) or mouse anti-myc monoclonal antibody (Oncogene).

\section{Confocal microscopy}

About $2.5 \times 10^{5}$ cells were seeded into $35-\mathrm{mm}$ culture dishes. After overnight incubation at $37^{\circ} \mathrm{C}$, the cells were transfected with $0.4 \mu \mathrm{g}$ of plasmid using the Effectene transfection kit (Qiagen, Germany). After transfection for $48 \mathrm{~h}$, recombinant proteins in the cells were analyzed. Cells were fixed by acetone/methanol $(1: 1)$ at $0^{\circ} \mathrm{C}$ for $10 \mathrm{~min}$. Fixed cells were washed with incubation buffer $\left(0.05 \% \mathrm{NaN}_{3}, 0.02 \%\right.$ saponin, $1 \%$ skim milk in PBS) twice for 5 min each time, then incubated with primary antibody (e.g., mouse anti-V5 monoclonal antibody, Invitrogen), which was diluted 200 fold, at $37^{\circ} \mathrm{C}$ for $30 \mathrm{~min}$. Samples were washed with PBS three times $(5 \mathrm{~min}$ each time at 
room temperature), then incubated with FITC-conjugated secondary antibody (e.g., goat anti-mouse $\operatorname{IgG}$ antibody, diluted $20 \times$ ) at $37^{\circ} \mathrm{C}$ for $30 \mathrm{~min}$. Samples were again washed with PBS three times (5-10 min each time at room temperature). DAPI (4', 6-diamidino-2-phenylindole) (Merck, Germany) was used to stain DNA to localize the cell nuclei. Samples were then observed with confocal microscopy. To quantify the average percentage of colocalization, the Image $\mathrm{J}$ (NIH website) program was used [25].

\section{Results}

$\mathrm{M}$ protein co-localization in cultured cells

SARS-CoV structural proteins localized in different subcellular positions when they were expressed individually (Fig. 1). When SARS-CoV M protein was co-expressed with other structural proteins (S, E, or NC), they were almost entirely co-localized with the other proteins (Fig. 2a); $\mathrm{R}=0.93,0.90,0.90$ for co-localization of $\mathrm{M}$ and $\mathrm{S}$ proteins, $\mathrm{M}$ and $\mathrm{NC}$ proteins, and $\mathrm{M}$ and $\mathrm{E}$ proteins, respectively. This result suggests that $\mathrm{M}$ protein binds to other structural proteins in the cultured cells. When $\mathrm{S}$ and $\mathrm{E}, \mathrm{S}$ and $\mathrm{NC}$, or $\mathrm{E}$ and $\mathrm{NC}$ were co-expressed in the cells, only partial co-localization was observed (Fig. 2b); $\mathrm{R}=0.54,0.70,0.85$ for co-localization of $\mathrm{E}$ and $\mathrm{S}$ proteins, $\mathrm{E}$ and $\mathrm{NC}$ proteins, and $\mathrm{NC}$ and $\mathrm{S}$ proteins, respectively.

\section{Binding between $\mathrm{M}$ and other structural proteins}

To verify whether SARS-CoV M protein and other structural proteins could bind to each other within cells, we performed a co-immunoprecipitation experiment. The V5-tagged, fulllength $\mathrm{M}$ protein and the myc-tagged $\mathrm{E}$ protein were coexpressed in Vero E6 cells by transient transfection. After transfection, cell lysates were immunoprecipitated with the anti-myc antibody, followed by Western blotting using the anti-V5 antibody. As shown in Fig. 3a, the V5-tagged M protein was immunoprecipitated by the anti-myc antibody in the presence (lane 8), but not in the absence (lane 6), of $\mathrm{E}$ protein. This result further confirmed that $\mathrm{M}$ and $\mathrm{E}$ proteins were bound to each other in the cultured cells. Similar coimmunoprecipitation experiments were performed to study the interactions between $\mathrm{M}$ and $\mathrm{S}$ proteins (Fig. 3b), and $\mathrm{M}$ and NC proteins (Fig. 3c). These results confirmed that $\mathrm{M}$ protein also bound $\mathrm{S}$ and NC proteins in the cultured cells.

Under the same experimental conditions (Supplementary Fig. 1a), the interaction between $\mathrm{E}$ and $\mathrm{M}$ but not the interaction between $\mathrm{E}$ and $\mathrm{S}$ was detected. Similarly, the interaction between $\mathrm{NC}$ and $\mathrm{M}$ but not the interaction between NC and E was demonstrated (Supplementary Fig. 1b). Moreover, the interaction between $\mathrm{NC}$ and $\mathrm{M}$ but not the interaction between NC and S was detected (Supplementary Fig. 1c).

Deletion mapping and $\mathrm{M}$ protein interactions with other structural proteins

To identify which region(s) of SARS-CoV $\mathrm{M}$ protein were interacting with $\mathrm{NC}$ protein, a deletion mapping experiment was performed. As shown in Fig. 4a, the V5-tagged $\mathrm{M}$ protein without the first 100 amino acids was immunoprecipitated by the anti-myc antibody in the presence (lane 8), but not in the absence (lane 6) of NC protein, while the first 100 amino acids of $\mathrm{M}$ protein with V5 tag could not be immunoprecipitated by the anti-myc antibody in the presence of the NC protein (Fig. 4b). This result indicates that the cytoplasmic C-terminus domain of SARS-CoV M protein was responsible for the binding with NC protein. To determine whether different topologies of the C-terminus domain of $\mathrm{M}$ protein could still interact with NC protein, the first (amino acids 21-37) or the second (amino acids 46-68) transmembrane domain of $\mathrm{M}$ protein was deleted. $M$ protein without the first transmembrane domain still left its C-terminus domain in the cytoplasm and it was not glycosylated, while $\mathrm{M}$ protein without the second transmembrane domain left its C-terminus domain in the endoplasmic reticulum lumen (Supplementary Fig. 2). As shown in Fig. 4c, M protein without the first transmembrane domain interacted with $\mathrm{NC}$ protein while $\mathrm{M}$ protein without the second transmembrane domain did not. To identify the regions within the cytoplasmic C-terminus domain of $\mathrm{M}$ protein responsible for binding to NC protein, different regions (amino acids 101135, 136-170, and 171-221) within the cytoplasmic Cterminus domain of $\mathrm{M}$ protein were deleted separately. As shown in Fig. 4d, all three $M$ deletion mutants still interacted with NC protein. Co-localization between the cytoplasmic C-terminus domain of $\mathrm{M}$ protein and $\mathrm{NC}$ protein was also demonstrated (upper panel, Fig. 7).

Deletion mapping was also performed to identify which domains of $\mathrm{M}$ protein interacted with $\mathrm{E}$ protein. The $\mathrm{C}$ terminal fragment from amino acids $171-221$ of $\mathrm{M}$ protein was truncated first. As shown in Fig. 5a, this truncated M protein still bound $\mathrm{E}$ protein. The first 50 amino acids of this truncated $\mathrm{M}$ protein were further deleted and still interacted with $\mathrm{E}$ protein. $\mathrm{M}$ protein without this region (amino acids 51-170) still interacted with E protein. These results suggest that multiple regions within $\mathrm{M}$ protein interacted with $\mathrm{E}$ protein. The second and third transmembrane regions (amino acids 46-68 and 78-100) of $\mathrm{M}$ protein by themselves, penetrated into the cell membrane, 


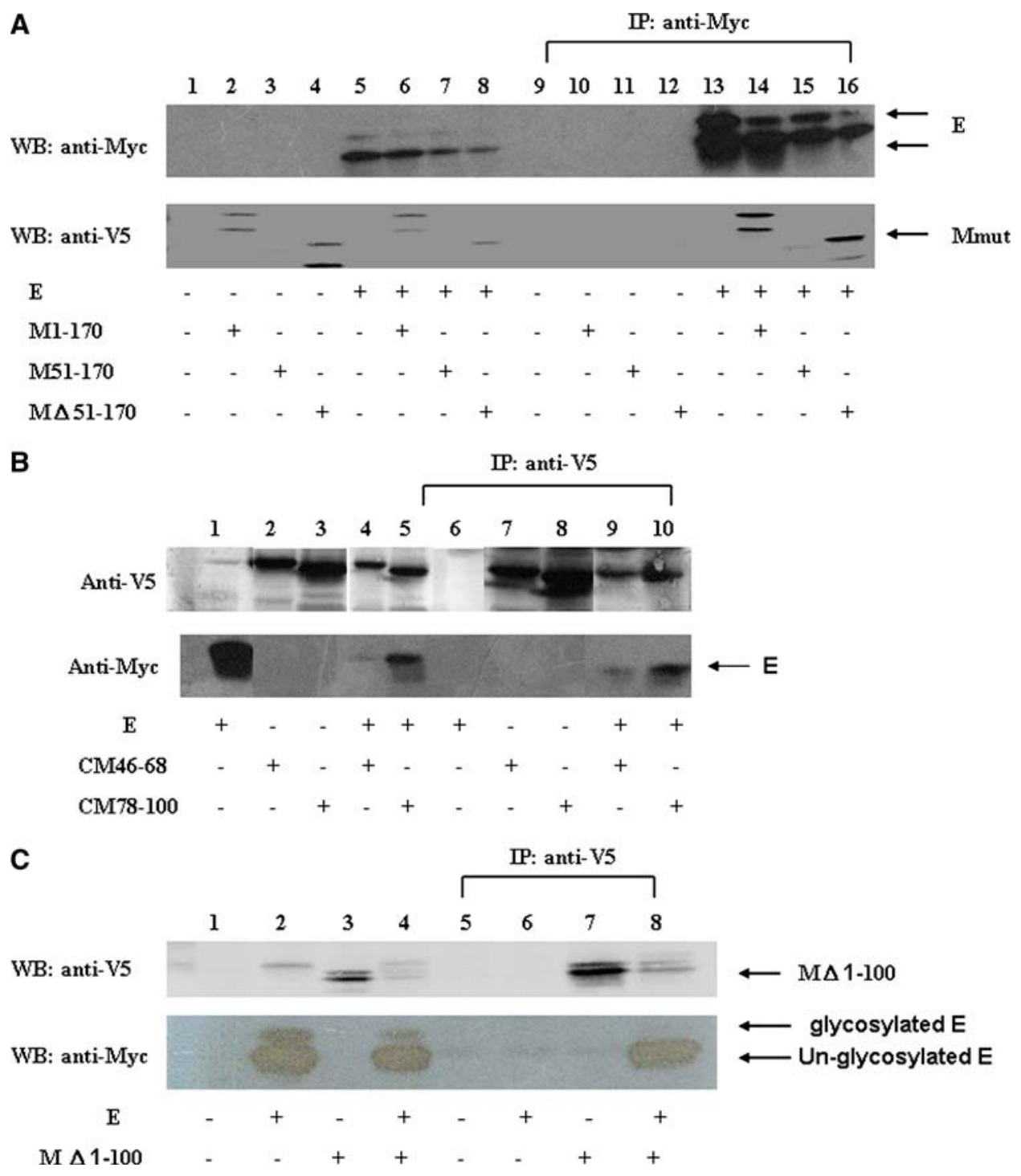

Fig. 5 Immunoprecipitation and Western blotting analyses of SARS$\mathrm{CoV} \mathrm{M}$ protein fragment interactions with $\mathrm{E}$ protein. (a) Interactions between SARS-CoV E and different M fragments. Vero E6 cells were transfected with vector alone, with the plasmid encoding M1-170 with a V5 tag (or the plasmid encoding M51-170 plus a V5 tag, or the plasmid encoding $\mathrm{M} \triangle 51-170$ plus a V5 tag), plasmid encoding mycE, or co-transfected with two plasmids (M1-170 and myc-E, M51170 and myc-E, $M \triangle 51-170$ and myc-E). Cell lysates were directly analyzed by Western blotting (lanes 1-8) or immunoprecipitated with the anti-myc antibody prior to Western blotting (lanes 9-18). (b) Vero E6 cells were transfected with the plasmid encoding myc-E protein, plasmid encoding the first 115 amino acids of HCV core protein and M protein amino acids 46-68 plus a V5 tag (the plasmid encoding the first 115 amino acids of $\mathrm{HCV}$ core protein and M protein amino acids 78-100 plus a V5 tag), or co-transfected with two plasmids. Cell

while the first transmembrane region (amino acids 14-36) was stabilized by interaction with the other transmembrane segments [25]. To determine whether the second or third transmembrane region alone interacted with $\mathrm{E}$ protein, these two transmembrane regions were fused with the first lysates were directly analyzed by Western blotting (lanes 1-4) or immunoprecipitated with the anti-V5 antibody prior to Western blotting (lanes 5-8). Either the second or the third transmembrane domain of $\mathrm{M}$ protein was sufficient for interaction with $\mathrm{E}$ protein. (c) Interactions between SARS-CoV E and the cytoplasmic C-terminus domain of $\mathrm{M}$ protein. Vero E6 cells were transfected with vector alone, plasmid encoding myc-E protein, plasmid encoding $\mathrm{M}$ protein without the first 100 amino acids plus a V5 tag, or co-transfected with both plasmids. Cell lysates were directly analyzed by Western blotting (lanes 1-4) or immunoprecipitated with the anti-V5 antibody prior to Western blotting (lanes 5-8) (lower panel). More than one band was detected when the plasmid encoding the cytoplasmic Cterminus domain of $\mathrm{M}$ protein was expressed, possibly due to sample preparation without boiling treatment

115 amino acids of $\mathrm{HCV}$ core protein separately [25]. As shown in Fig. 5b, the second or the third transmembrane region of $\mathrm{M}$ protein alone was sufficient to bind $\mathrm{E}$ protein. Furthermore, the cytoplasmic C-terminus domain of $\mathrm{M}$ protein (i.e. M protein without its first 100 amino acids) 
A IP: anti-Myc

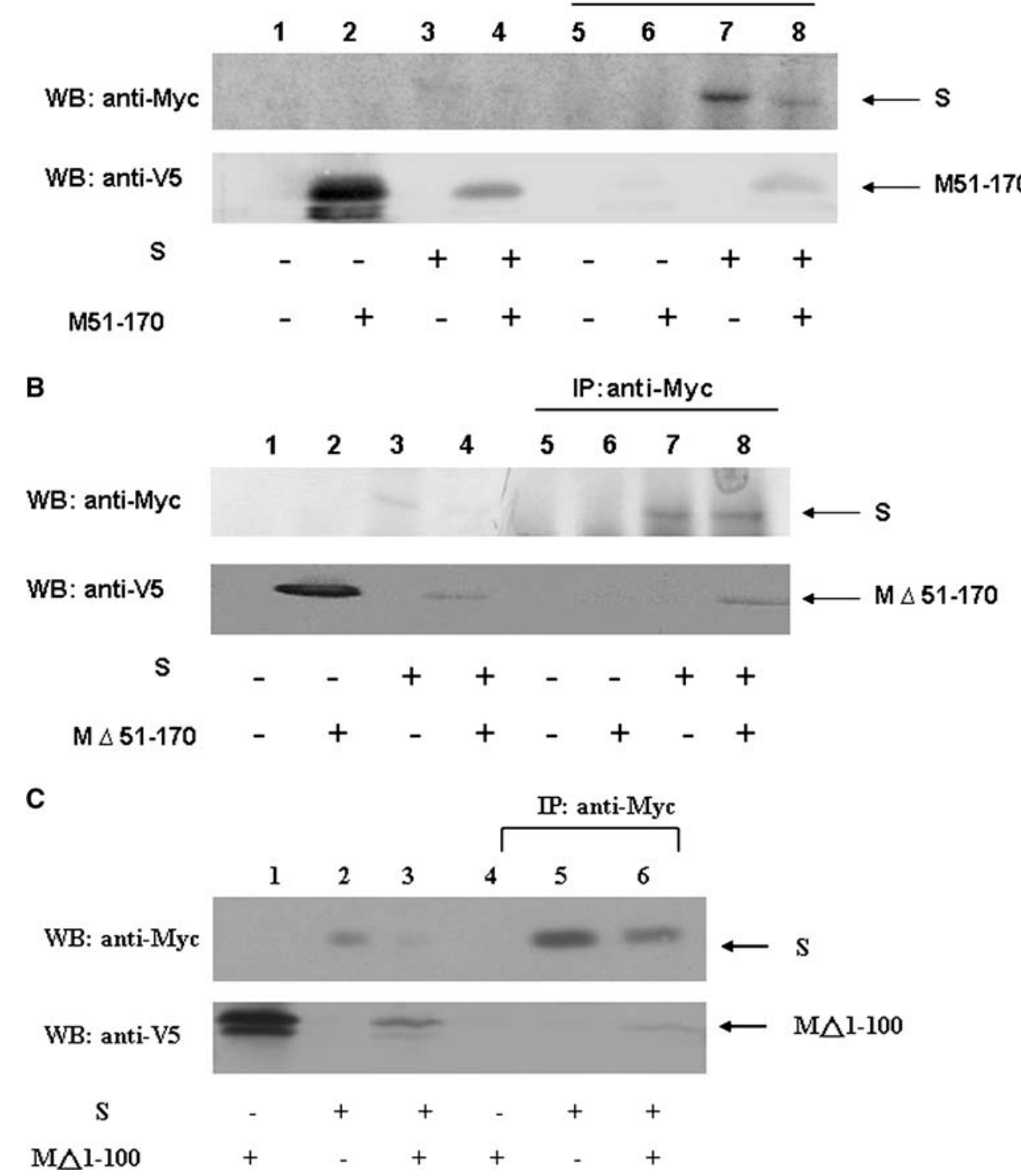

Fig. $6 \mathrm{M}$ protein interaction with $\mathrm{S}$ protein. (a) Vero E6 cells were transfected with vector alone (lanes 1 and 5), plasmid encoding M51170 with a V5 tag (lanes 2 and 6), plasmid encoding myc-S (lanes 3 and 7), or co-transfected with both plasmids (lanes 4 and 8). Cell lysates were directly analyzed by Western blotting (lanes 1-4) or immunoprecipitated with the anti-myc antibody prior to Western blotting (lanes 5-8). (b) Similar to (a), except the plasmid encoding $\mathrm{M} \triangle 51-170$ plus a V5 tag was used to replace the plasmid encoding M51-170 with a V5 tag. (c) Interactions between SARS-CoV S and

also interacted with $\mathrm{E}$ protein (Fig. 5c). In this case, the unglycosylated, but not glycosylated, E protein was preferentially immunoprecipitated. Co-localization between the cytoplasmic C-terminus domain of $\mathrm{M}$ protein and $\mathrm{E}$ protein was also demonstrated (middle panel, Fig. 7).

The $\mathrm{M}$ mutant constructs were also used to map the binding region(s) of $\mathrm{M}$ protein with $\mathrm{S}$ protein. As shown in Fig. 6a, M protein containing only amino acids 51-170 cytoplasmic C-terminus domain of M protein. Similar to (a), except the plasmid encoding $M$ protein without the first 100 amino acids plus a V5 tag was used to replace the plasmid encoding M51-170 with a V5 tag (lower panel). More than one band was detected when the plasmid encoding cytoplasmic domain of $\mathrm{M}$ protein was expressed possibly due to the sample preparation without boiling treatment. The results show that multiple regions of $M$ protein interacted with $S$ protein

interacted with $\mathrm{S}$ protein. $\mathrm{M}$ protein without this region also interacted with $\mathrm{S}$ protein (Fig. 6b). Again, the cytoplasmic $\mathrm{C}$-terminus domain of $\mathrm{M}$ protein was also sufficient to interact with $\mathrm{S}$ protein (Fig. 6c). These results suggest that multiple regions within $\mathrm{M}$ protein interacted with S protein. Co-localization between the cytoplasmic Cterminus domain of $\mathrm{M}$ protein and $\mathrm{S}$ protein was also demonstrated (lower panel of Fig. 7). 


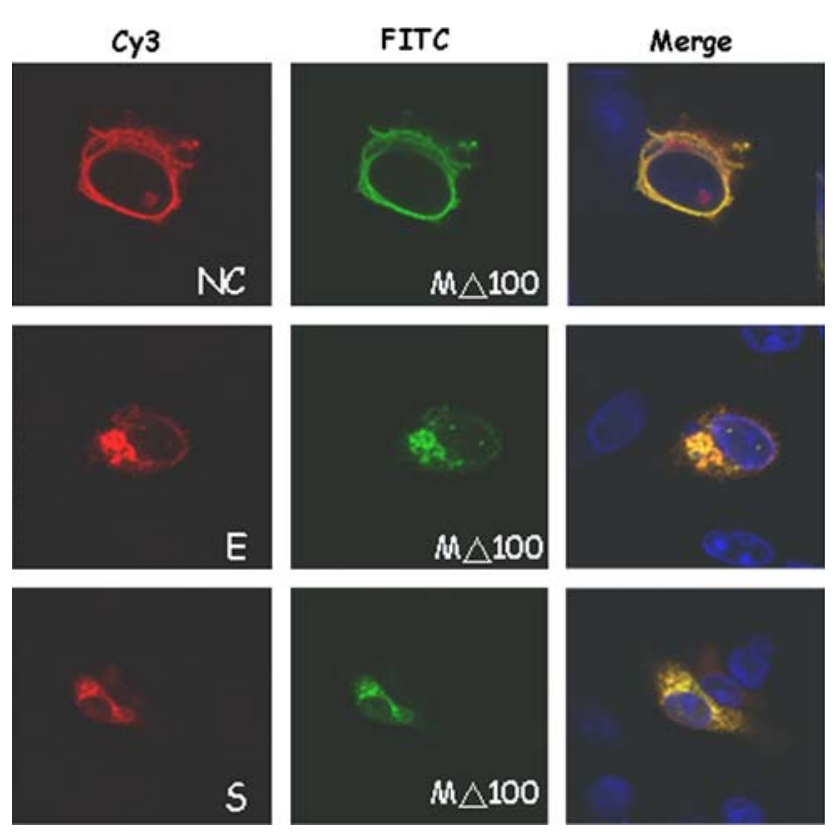

Fig. 7 Co-localization of $\mathrm{M} \triangle 1-100$ protein and $\mathrm{NC}$ (upper panel), E (middle panel), and $\mathrm{S}$ (lower panel) proteins. Similar to Fig. 2a, except the plasmid encoding $M$ protein without the first 100 amino acids plus a V5 tag was used to replace the plasmid encoding M protein with a V5 tag

\section{Discussion}

SARS-CoV structural proteins (S, E, M, and NC) localized to different subcellular positions when they were expressed individually (Fig. 1), similar to the results of a previous report [30]. SARS-CoV M protein co-localized almost entirely with $\mathrm{S}, \mathrm{E}$, or $\mathrm{NC}$ proteins when they were co- expressed within the cells (Fig. 2a). On the other hand, only partial co-localization was observed when $\mathrm{S}$ and $\mathrm{E}, \mathrm{S}$ and $\mathrm{NC}$, or $\mathrm{E}$ and $\mathrm{NC}$ were co-expressed in the cells (Fig. 2b). Furthermore, the interactions between $M$ and the other structural proteins were demonstrated by co-immunoprecipitation (Fig. 3). The interactions of E and S, E and $\mathrm{NC}, \mathrm{NC}$ and $\mathrm{S}$ proteins were not demonstrated by coimmunoprecipitation (Supplementary Fig. 1). These results suggest that SARS-CoV M protein plays a pivotal role in virus assembly. Interactions of $\mathrm{S}$ and $\mathrm{E}, \mathrm{S}$ and $\mathrm{NC}$, or $\mathrm{E}$ and $\mathrm{NC}$ could occur after binding with $\mathrm{M}$ protein.

Previous studies reported that virus-like particles (VLP) formed when either SARS-CoV $\mathrm{M}$ and $\mathrm{E}$ proteins [31] or $\mathrm{M}$ and NC proteins [32] were co-expressed in cells. We hypothesize that $M$ protein plays a crucial role in virus assembly and our study results support this hypothesis.

SARS-CoV M protein appears to be a triple-spanning membrane protein [33], while NC protein is a cytoplasmic protein. Due to the topology of these two proteins, $M$ protein is supposed to interact with NC through its cytoplasmic C-terminus domain. Indeed, as shown in Fig. 4, only the $\mathrm{C}$-terminus domain of $\mathrm{M}$ protein residing in the cytoplasm interacted with NC protein. The result that three $\mathrm{M}$ deletion mutants ( $\mathrm{M}$ protein without amino acids 101135, 136-170, or 171-221) interacted with NC protein (Fig. 4d) suggests that almost the entire C-terminus domain of $\mathrm{M}$ protein is responsible for the interaction with $\mathrm{NC}$ protein. Our results agree with those of previous reports using in vitro GST pull-downed assays [34] or yeast twohybrid and surface plasmon resonance techniques [35] to study the interactions between SARS-CoV $\mathrm{M}$ and $\mathrm{NC}$ proteins.

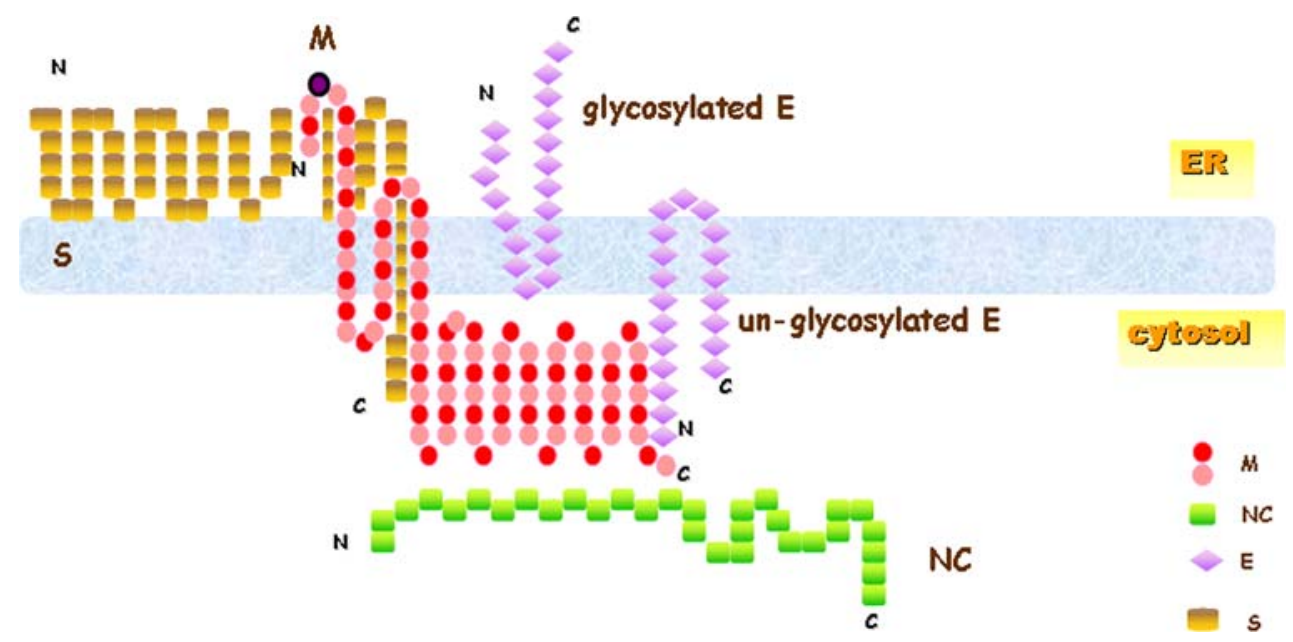

Fig. 8 A proposed model for the interactions between the $M$ protein and other structural proteins of SARS-CoV. M protein probably interacts with unglycosylated $\mathrm{E}$ protein through cytoplasmic Cterminus regions first. After glycosylation of $\mathrm{E}$ protein, interaction between $\mathrm{M}$ and $\mathrm{E}$ proteins are possibly through transmembrane regions, and the freed cytoplasmic region of $M$ protein will then interact with $\mathrm{NC}$ protein. S protein could incorporate into virus-like particles formed by $\mathrm{M}$ and $\mathrm{E}$ proteins through interacting with multiple regions of $\mathrm{M}$ protein 
That at least two transmembrane domains and the cytoplasmic domain of $\mathrm{M}$ protein are sufficient for the interacting with $\mathrm{E}$ protein (Fig. 5) suggest extensive interactions between these two proteins. Compared with other constructs, the cytoplasmic C-terminus domain of $\mathrm{M}$ protein preferentially immunoprecipitated unglycosylated, but not glycosylated, E protein (Fig. 5c). This result supports a previously reported model for the topology of $\mathrm{E}$ protein [36]: unglycosylated $\mathrm{E}$ protein leaves both its $\mathrm{N}$ and C-termini in the cytoplasm while glycosylated $\mathrm{E}$ protein leaves both its $\mathrm{N}$ - and $\mathrm{C}$-termini in the endoplasmic reticulum lumen.

Similar to the interactions of $\mathrm{M}$ and $\mathrm{S}$ proteins in another coronaviruses [37], SARS-CoV M protein interacted with $S$ protein through multiple regions (Fig. 6). A model for the interactions between SARS-CoV M protein and other structural proteins was proposed (Fig. 8). While SARS-CoV structural proteins ( $\mathrm{S}, \mathrm{E}, \mathrm{M}$, and NC) reside in different subcellular locales, $M$ protein brings other structural proteins $(\mathrm{NC}, \mathrm{S}$, and $\mathrm{E})$ together through interacting with them. After that, interactions of $\mathrm{S}$ and $\mathrm{E}, \mathrm{S}$ and $\mathrm{NC}$, or $\mathrm{E}$ and $\mathrm{NC}$ occur.

Acknowledgement This work has been supported by grants from Tzu Chi University (TCIRP95002-01 and TCIRP96004-05) and from National Science Council of Taiwan (NSC 96-3112-B-320-001) to Dr. Shih-Yen Lo.

\section{References}

1. Poon LL, Guan Y, Nicholls JM, Yuen KY, Peiris JS (2004) The aetiology, origins, and diagnosis of severe acute respiratory syndrome. Lancet Infect Dis 4:663-671

2. Rota PA, Oberste MS, Monroe SS, Nix WA, Campagnoli R, Icenogle JP, Penaranda S, Bankamp B, Maher K, Chen MH, Tong S, Tamin A, Lowe L, Frace M, DeRisi JL, Chen Q, Wang D, Erdman DD, Peret TC, Burns C, Ksiazek TG, Rollin PE, Sanchez A, Liffick S, Holloway B, Limor J, McCaustland K, Olsen-Rasmussen M, Fouchier R, Gunther S, Osterhaus AD, Drosten C, Pallansch MA, Anderson LJ, Bellini WJ (2003) Characterization of a novel coronavirus associated with severe acute respiratory syndrome. Science 300:1394-1399

3. Peiris JS, Lai ST, Poon LL, Guan Y, Yam LY, Lim W, Nicholls J, Yee WK, Yan WW, Cheung MT, Cheng VC, Chan KH, Tsang DN, Yung RW, Ng TK, Yuen KY, SARS study group (2003) Coronavirus as a possible cause of severe acute respiratory syndrome. Lancet 361:1319-1325

4. Kuiken T, Fouchier RA, Schutten M, Rimmelzwaan GF, van Amerongen G, van Riel D, Laman JD, de Jong T, van Doornum G, Lim W, Ling AE, Chan PK, Tam JS, Zambon MC, Gopal R, Drosten C, van der Werf S, Escriou N, Manuguerra JC, Stohr K, Peiris JS, Osterhaus AD (2003) Newly discovered coronavirus as the primary cause of severe acute respiratory syndrome. Lancet 362:263-270

5. Gu J, Gong E, Zhang B, Zheng J, Gao Z, Zhong Y, Zou W, Zhan J, Wang S, Xie Z, Zhuang H, Wu B, Zhong H, Shao H, Fang W, Gao D, Pei F, Li X, He Z, Xu D, Shi X, Anderson VM, Leong AS
(2005) Multiple organ infection and the pathogenesis of SARS. J Exp Med 202:415-424

6. Wang H, Rao S, Jiang C (2007) Molecular pathogenesis of severe acute respiratory syndrome. Microbes Infect 9:119-126

7. Enserink M (2003) Infectious diseases. Clues to the animal origins of SARS. Science 300:1351

8. Holmes KV, Enjuanes L (2003) Virology. The SARS coronavirus: a postgenomic era. Science 300:1377-1378

9. Lai M (2003) SARS virus: the beginning of the unraveling of a new coronavirus. J Biomed Sci 10:664-675

10. Holmes K, Lai MM (1996) Coronaviridae: the viruses and their replication. In: Fields BN, Knipe DM, Howley PM (eds) Fields virology, vol 1. Lippincott-Raven Publishers, Philadelphia, pp 1075-1093

11. Thiel V, Ivanov KA, Putics A, Hertzig T, Schelle B, Bayer S, Weissbrich B, Snijder EJ, Rabenau H, Doerr HW, Gorbalenya AE, Ziebuhr J (2003) Mechanisms and enzymes involved in SARS coronavirus genome expression. J Gen Virol 84:23052315

12. Nguyen VP, Hogue BG (1997) Protein interactions during coronavirus assembly. J Virol 71:9278-9284

13. Nguyen VP, Hogue BG (1998) Coronavirus envelope glycoprotein assembly complexes. Adv Exp Med Biol 440:361-365

14. Vennema H, Godeke GJ, Rossen JW, Voorhout WF, Horzinek MC, Opstelten DJ, Rottier PJ (1996) Nucleocapsid-independent assembly of coronavirus-like particles by co-expression of viral envelope protein genes. EMBO J 15:2020-2028

15. de Haan CA, Kuo L, Masters PS, Vennema H, Rottier PJ (1998) Coronavirus particle assembly: primary structure requirements of the membrane protein. J Virol 72:6838-6850

16. Narayanan K, Maeda A, Maeda J, Makino S (2000) Characterization of the coronavirus $M$ protein and nucleocapsid interaction in infected cells. J Virol 74:8127-8134

17. Godeke GJ, de Haan CA, Rossen JW, Vennema H, Rottier PJ (2000) Assembly of spikes into coronavirus particles is mediated by the carboxy-terminal domain of the spike protein. J Virol 74:1566-1571

18. Opstelten DJ, Raamsman MJ, Wolfs K, Horzinek MC, Rottier PJ (1995) Envelope glycoprotein interactions in coronavirus assembly. J Cell Biol 131:339-349

19. Rottier P, Brandenburg D, Armstrong J, van der Zeijst B, Warren $\mathrm{G}$ (1984) In vitro assembly of the murine coronavirus membrane protein E1. Adv Exp Med Biol 173:53-64

20. Rottier PJ, Welling GW, Welling-Wester S, Niesters HG, Lenstra JA, Van der Zeijst BA (1986) Predicted membrane topology of the coronavirus protein E1. Biochemistry 25:1335-1339

21. Stertz S, Reichelt M, Spiegel M, Kuri T, Martinez-Sobrido L, Garcia-Sastre A, Weber F, Kochs G (2007) The intracellular sites of early replication and budding of SARS-coronavirus. Virology 361:304-315

22. McBride CE, Li J, Machamer CE (2007) The cytoplasmic tail of the severe acute respiratory syndrome coronavirus spike protein contains a novel endoplasmic reticulum retrieval signal that binds COPI and promotes interaction with membrane protein. J Virol $81: 2418-2428$

23. Hsieh PK, Chang SC, Huang CC, Lee TT, Hsiao CW, Kou YH, Chen IY, Chang CK, Huang TH, Chang MF (2005) Assembly of severe acute respiratory syndrome coronavirus RNA packaging signal into virus-like particles is nucleocapsid dependent. J Virol 79:13848-13855

24. Lee YN, Chen LK, Ma HC, Yang HH, Li HP, Lo SY (2005) Thermal aggregation of SARS-CoV membrane protein. J Virol Methods 129:152-161

25. Ma HC, Fang CP, Hsieh YC, Chen SC, Li HC, Lo SY (2008) Expression and membrane integration of SARS-CoV M protein. $\mathrm{J}$ Biomed Sci 15:301-310 
26. Ma HC, Ku YY, Hsieh YC, Lo SY (2007) Characterization of the cleavage of signal peptide at the $\mathrm{C}$-terminus of hepatitis $\mathrm{C}$ virus core protein by signal peptide peptidase. J Biomed Sci 14:31-41

27. Fuerst TR, Niles EG, Studier FW, Moss B (1986) Eukaryotic transient-expression system based on recombinant vaccinia virus that synthesizes bacteriophage T7 RNA polymerase. Proc Natl Acad Sci USA 83:8122-8126

28. Ma HC, Ke CH, Hsieh TY, Lo SY (2002) The first hydrophobic domain of the hepatitis $\mathrm{C}$ virus $\mathrm{E} 1$ protein is important for interaction with the capsid protein. J Gen Virol 83:3085-3092

29. Ma HC, Lin TW, Li H, Iguchi-Ariga SM, Ariga H, Chuang YL, Ou JH, Lo SY (2008) Hepatitis C virus ARFP/F protein interacts with cellular MM-1 protein and enhances the gene trans-activation activity of c-Myc. J Biomed Sci 15:417-425

30. Nal B, Chan C, Kien F, Siu L, Tse J, Chu K, Kam J, Staropoli I, Crescenzo-Chaigne B, Escriou N, van der Werf S, Yuen KY, Altmeyer R (2005) Differential maturation and subcellular localization of severe acute respiratory syndrome coronavirus surface proteins S, M and E. J Gen Virol 86:1423-1434

31. Ho Y, Lin PH, Liu CY, Lee SP, Chao YC (2004) Assembly of human severe acute respiratory syndrome coronavirus-like particles. Biochem Biophys Res Commun 318:833-838

32. Huang Y, Yang ZY, Kong WP, Nabel GJ (2004) Generation of synthetic severe acute respiratory syndrome coronavirus pseudoparticles: implications for assembly and vaccine production. J Virol 78:12557-12565

33. Hirokawa T, Boon-Chieng S, Mitaku S (1998) SOSUI: classification and secondary structure prediction system for membrane proteins. Bioinformatics 14:378-379

34. Fang X, Ye L, Timani KA, Li S, Zen Y, Zhao M, Zheng H, Wu Z (2005) Peptide domain involved in the interaction between membrane protein and nucleocapsid protein of SARS-associated coronavirus. J Biochem Mol Biol 38:381-385

35. Luo H, Wu D, Shen C, Chen K, Shen X, Jiang H (2006) Severe acute respiratory syndrome coronavirus membrane protein interacts with nucleocapsid protein mostly through their carboxyl termini by electrostatic attraction. Int $\mathrm{J}$ Biochem Cell Biol 38:589-599

36. Yuan Q, Liao Y, Torres J, Tam JP, Liu DX (2006) Biochemical evidence for the presence of mixed membrane topologies of the severe acute respiratory syndrome coronavirus envelope protein expressed in mammalian cells. FEBS Lett 580:3192-3200

37. de Haan CA, Smeets M, Vernooij F, Vennema H, Rottier PJ (1999) Mapping of the coronavirus membrane protein domains involved in interaction with the spike protein. J Virol 73:74417452 